\title{
Serum Ghrelin Levels in Patients with Chronic Urticaria and Atopic Dermatitis and Its
}

\section{Relation with Metabolic Syndrome}

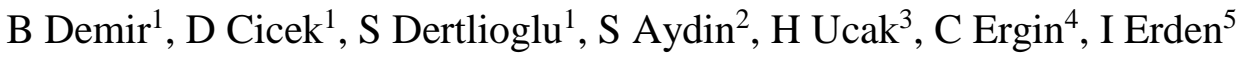

\begin{abstract}
Objective: Chronic urticaria is a systemic inflammatory disease. Atopic dermatitis is a chronic immunological disease that is characterized by an increase in systemic inflammatory response. In several studies, chronic urticaria and atopic dermatitis were reported to be associated metabolic syndrome (MetS). In this study, we aimed to investigate the serum ghrelin levels in the patients with chronic urticaria and atopic dermatitis.

Methods: Thirty patients with chronic urticaria, 30 patients with atopic dermatitis and 30 control subjects participated in this study. Blood fasting glucose and serum lipids, insulin, C-peptide levels and thyroid function tests were measured. The homeostasis model assessment of insulin resistance (HOMA-IR) was used to calculate insulin resistance. Ghrelin levels were determined by enzyme-linked immunosorbent assay (ELISA) according to the manufacturer's protocol.
\end{abstract}

Results: The mean serum ghrelin levels in the patients with chronic urticaria $(54.13 \pm 40.94$ $\mathrm{pg} / \mathrm{mL})$ and atopic dermatitis $(65.33 \pm 93.54 \mathrm{pg} / \mathrm{mL})$ were significantly higher than those of the controls $[30.36 \pm 17.13 \mathrm{pg} / \mathrm{mL}](\mathrm{p}=0.003, \mathrm{p}=0.04$, respectively).

Conclusion: We detected higher serum ghrelin levels in the patients with chronic urticaria and atopic dermatitis than the controls. However, we failed to find any association between serum ghrelin levels and insulin resistance or MetS. We think that, the high levels of serum ghrelin in the patients with chronic urticaria and atopic dermatitis may be related to the mechanisms independent of insulin resistance.

Keywords: Atopic dermatitis, chronic urticaria, ghrelin

From: ${ }^{1}$ Department of Dermatology, Firat University Hospital, Elazig, Turkey, ${ }^{2}$ Department of Biochemistry and Clinical Biochemistry, Firat University Hospital, ${ }^{3}$ Department of Dermatology, Dicle University Hospital, Diyarbakir, Turkey, ${ }^{4}$ Dışkapı 1 Yıldırım Beyazıt Education and Research Hospital, Dermatology Specialist, Ankara, Turkey and ${ }^{5}$ Clinic of Dermatology, Dermatology Specialist, Elazig Education and Research Hospital, Elazig, Turkey.

Correspondence: Dr Demir, Department of Dermatology, Firat University Hospital, Elazig, Turkey. Tel number: +90 424233 3555, Fax number: +90 4242388096.

E-mail: drbkaraca@yahoo.com 


\section{INTRODUCTION}

Chronic urticaria is defined as urticaria or angioedema or both persists for longer than six weeks. Numerous mediators such as histamin, leukotrienes, serin proteases, heparin, triptase and proinflammatory cytokines trigger mast cell degranulation. Urticaria is related with atopic dermatitis and allergic rhinitis especially in childhood (1). Atopic dermatitis is accepted as a chronic, systemic immunologic disease with a tendency to increase in inflammatory response. In atopic dermatitis, antigenic stimulation of langerhans cells, mast cells and keratinocytes cause an increase in eosinophils, inflammatory dendritic cells and Th2 response (2).

Ghrelin is a peptide hormone mainly secreted by gastric mucosa (3). Ghrelin has many important functions such as stimulating growth, appetite, lipid storage and gluconeogenesis, controling gastric motility and gastric acid secretion, regulating pancreatic exocrine and endocrine secretions, proliferation of neoplastic cells and regulating immune system $(4,5)$. Increased plasma ghrelin levels were observed in obese individuals in a number of studies and high plasma ghrelin level was considered to be a feature of metabolic syndrome (MetS) like hyperinsulinemia and insülin resistance $(6,7)$.

Recently, there have been some studies reporting the relation between chronic urticaria and MetS (8). Atopic dermatitis is considered to be a risk factor for MetS (9). The aim of this study is to evaluate serum ghrelin level and its relation with MetS in the patients with chronic urticaria and atopic dermatitis. 


\section{METHODS}

The local ethics committee approved the study (no:03 of 21.02.2013). Informed consent was obtained from all the participants. Thirty patients with chronic urticaria, 30 patients with atopic dermatitis and 30 healthy control subjects were enrolled into the study. The diagnosis of chronic urticaria and atopic dermatitis were based on clinical findings and Hanifin-rajka diagnostic criteria, respectively (10).

The participants under the age of 18 , having systemic diseases, having malignancy or infection, being pregnant, using systemic medications were excluded from the study. The patients with chronic urticaria and atopic dermatitis taking systemic corticosteroids or any immunosuppressive drug for the last three months were also excluded.

Body mass index (BMI) was calculated according to the formula of $[\mathrm{BMI}=$ weight $(\mathrm{kg}) /$ height $\left.{ }^{2}\left(\mathrm{~m}^{2}\right)\right]$. Score 0:18.5-24.9 kg/m², score 1: $25.0-29.9 \mathrm{~kg} / \mathrm{m}^{2}$, score 2: 30.0-39.9 $\mathrm{kg} / \mathrm{m}^{2}$, score $3: \geq 40.0 \mathrm{~kg} / \mathrm{m}^{2}$. BMI values over 30 were accepted as obese (11).

Serum fasting glucose level, triglyceride, total cholesterol, LDL, VLDL and HDL cholesterol, insulin, C-peptide and thyroid function tests were measured. The diagnosis of MetS was based on the diagnostic criteria of International Diabetes Federation (IDF). The participants having two or more criteria below were accepted as MetS. The diagnostic criteria of IDF for MetS: Waist circumference $\geq 94 \mathrm{~cm} \mathrm{(male)} \mathrm{or} \geq 80 \mathrm{~cm}$ (female), hypertriglyceridemia $\geq 150 \mathrm{mg} / \mathrm{dL}, \mathrm{HDL}$ cholesterol $<40 \mathrm{mg} / \mathrm{dL}$ (male) or $<50 \mathrm{mg} / \mathrm{dL}$ (female), arterial blood pressur e $\geq 130 / 85 \mathrm{~mm} \mathrm{Hg}$, serum fasting glucose level $\geq 100 \mathrm{mg} / \mathrm{dL}$ (12). Homeostasis model assessment for insulin resistance (HOMA-IR) index was used to measure insulin resistance (HOMA-IR = insulin (mU/L) x glucose [mmol/L)/ 22.5] (13).

Ghrelin is sensitive to proteases because of its peptide structure. Therefore, aprotinin (500 kallikrein unite/mL) was added into the blood collection tubes before the blood samples were collected from the patients to prevent proteolysis. The blood samples were collected 
between 09:00 am-10:00 am after an overnight fast of at least 8 hours. The blood samples (5 mL) were centrifuged at $3000 \mathrm{rpm}$. The serum samples were transferred into microsentrifuge tubes and stored at $-80{ }^{\circ} \mathrm{C}$ freezer. Serum ghrelin levels were determined with enzyme-linked immunosorbent assay (ELISA kits cat. no:SPI BIO-A05106).

The statistical analysis was carried out using the Statistical Package for the Social Sciences (SPSS) version 22. Continuous data are expressed as the mean \pm SD. Comparisons between the groups were assessed using student's $t$-test and Mann-Whitney-U test, $p$-values less than 0.05 were considered statistically significant.

\section{RESULTS}

The ages of urticaria patients were between $18-67$, the atopic dermatitis patients were $18-52$, the controls were $18-45$. The mean age of the urticaria patients, atopic dermatitis patients and the control group were $34.43 \pm 12.9,29.70 \pm 11.4,30.90 \pm 8.5$, respectively. There was no significant difference between the groups in terms of mean age, gender and BMI $(p>0.05)$ (Table 1).

Table 1. Clinical features of the patients and the controls

\begin{tabular}{lllll}
\hline & Urticaria & Atopic dermatitis & Control & $p$ \\
\hline Number & 30 & 30 & 30 & \\
Gender (M/F) & $15 / 15$ & $15 / 15$ & $15 / 15$ & $p>0.05$ \\
Age* (year) & $34.43 \pm 12.9$ & $29.70 \pm 11.4$ & $30.90 \pm 8.5$ & $p>0.05$ \\
BMI* (kg/m $\left.^{2}\right)$ & $26.08 \pm 6.31$ & $24.21 \pm 5.50$ & $23.71 \pm 3.25$ & $p>0.05$ \\
BMI score* & $2.63 \pm 1.03$ & $2.48 \pm 1.05$ & $2.30 \pm 0.79$ & $p>0.05$ \\
$\begin{array}{l}\text { Waist } \\
\text { circumference*(cm) }\end{array}$ & $76.43 \pm 11.76$ & $78.70 \pm 21.45$ & $78.90 \pm 7.44$ & $p>0.05$ \\
\hline
\end{tabular}

$*($ Mean \pm SD) 
The the mean serum ghrelin levels were significantly higher in the chronic urticaria $(54.13 \pm$ $40.94, p=0.003)$ and in the atopic dermatitis patients $(65.33 \pm 93.54, p=0.04)$ than in the controls $(30.36 \pm 17.13)$. There was no significant difference between the mean serum ghrelin levels of the chronic urticaria and atopic dermatitis patients $(p>0.05)$. The laboratory findings of the patient and control groups are shown in Table 2 and Figure 1.

Table 2. Laboratory results of the patient and the control groups

\section{Urticaria Atopic Dermatitis Control p}

\begin{tabular}{|c|c|c|c|c|}
\hline $\begin{array}{l}\text { Glucose* } \\
(\mathrm{mg} / \mathrm{dL})\end{array}$ & $100.76 \pm 32.07$ & $92.73 \pm 11.41$ & $89.80 \pm 9.71$ & $p>0.05$ \\
\hline $\begin{array}{l}\text { Trigliceride* } \\
(\mathrm{mg} / \mathrm{dL})\end{array}$ & $114.30 \pm 50.41$ & $89.76 \pm 43.78$ & $115.13 \pm 80.08$ & $p>0.05$ \\
\hline $\begin{array}{l}\text { LDL-cholesterol* } \\
\text { (mg/dL) }\end{array}$ & $96.58 \pm 36.12$ & $98.44 \pm 31.20$ & $92.60 \pm 30.42$ & $p>0.05$ \\
\hline $\begin{array}{l}\text { HDL- } \\
\text { cholesterol* } \\
(\mathrm{mg} / \mathrm{dL})\end{array}$ & $50.60 \pm 13.20$ & $51.80 \pm 11.09$ & $49.15 \pm 13.06$ & $p>0.05$ \\
\hline $\begin{array}{l}\text { Total } \\
\text { cholesterol* } \\
(\mathrm{mg} / \mathrm{dL})\end{array}$ & $167.53 \pm 44.04$ & $167.40 \pm 37.51$ & $168.90 \pm 24.04$ & $p>0.05$ \\
\hline $\begin{array}{l}\text { Insulin* } \\
(\mu \mathrm{IU} / \mathrm{mL})\end{array}$ & $8.40 \pm 3.05$ & $8.90 \pm 3.62$ & $10.77 \pm 5.74$ & $p>0.05$ \\
\hline $\begin{array}{l}\text { C-peptide* } \\
(\mathbf{n g} / \mathbf{m L})\end{array}$ & $0.90 \pm 0.59$ & $1.15 \pm 0.58$ & $2.07 \pm 0.78$ & $p>0.05$ \\
\hline HOMA-IR* & $2.17 \pm 1.54$ & $2.05 \pm 0.92$ & $2.35 \pm 1.27$ & $p>0.05$ \\
\hline Ghrelin* (pg/mL) & $54.13 \pm 40.94^{\mathrm{a}}$ & $65.33 \pm 93.54^{b}$ & $30.36 \pm 17.13^{\mathrm{a}, \mathrm{b}}$ & $\begin{aligned}{ }^{\mathrm{a}} p & =\mathbf{0 . 0 0 3} \\
{ }^{\mathrm{b}} p & =\mathbf{0 . 0 4}\end{aligned}$ \\
\hline
\end{tabular}

$*($ Mean $\pm \mathrm{SD})$ 


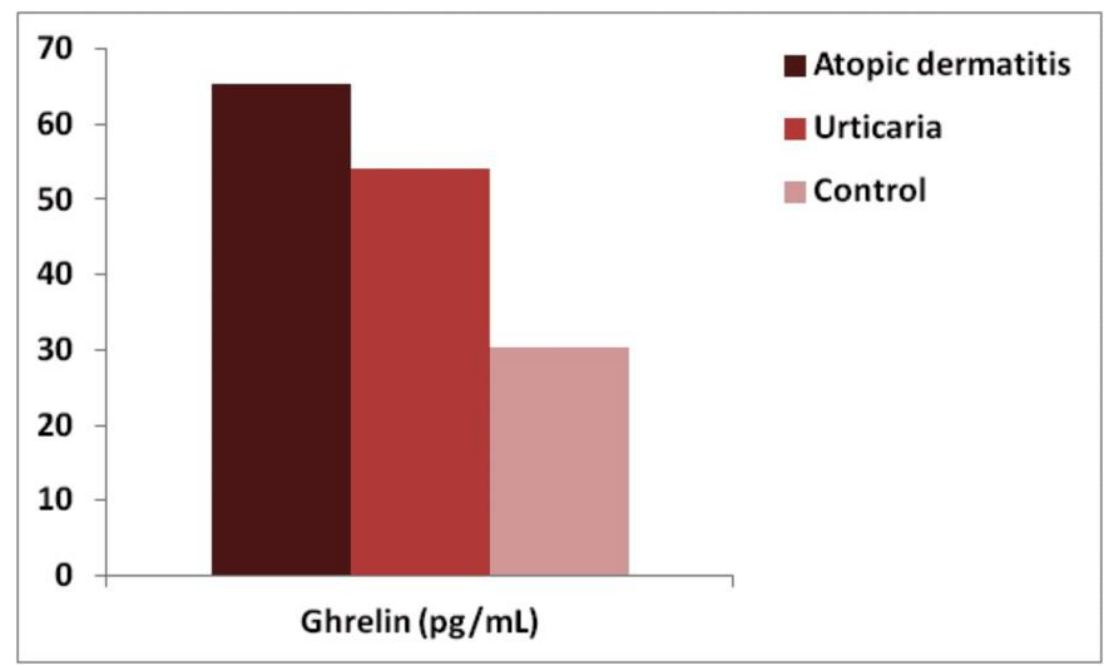

Figure: The laboratory findings of the patient and control groups

Increased insulin resistance was detected in $11(36.7 \%)$ of the chronic urticaria patients, in six $(20 \%)$ of the atopic dermatit patients and in $8(26.7 \%)$ of the controls. Although the mean serum ghrelin levels of the chronic urticaria patients with insulin resistance $(73.67 \pm 52.49 \mathrm{pg} / \mathrm{mL})$ was higher than the chronic urticaria patients without insulin resistance $(42.81 \pm 28.32 \mathrm{pg} / \mathrm{mL})$, the difference was not statistically significant $(p>0.05)$. The mean serum ghrelin levels of the atopic dermatitis patients with insülin resistance $(50.47 \pm 23.95 \mathrm{pg} / \mathrm{mL})$ was lower than those of the atopic dermatitis patients without insülin resistance $(69.04 \pm 104.09 \mathrm{pg} / \mathrm{mL})$ but the difference was not statistically significant $(p>0.05)$. The mean serum ghrelin levels of two patient groups with insulin resistance $(65.48 \pm 45.07 \mathrm{pg} / \mathrm{mL})$ was higher than those of the patients without insulin resistance $(57.45 \pm 80.37 \mathrm{pg} / \mathrm{mL})$. The difference was not statistically significant $(p>0.05)$.

MetS was found in five $(16.7 \%)$ of the urticaria patients, in five $(16.7 \%)$ of the atopic dermatitis patients and in one $(3.3 \%)$ of the controls. The mean serum ghrelin level of all the 
patients with MetS $(65.23 \pm 42.67 \mathrm{pg} / \mathrm{mL})$ and the mean level of the patients without MetS $(57.18 \pm 82.25 \mathrm{pg} / \mathrm{mL})$ were similar $(p>0.05)$.

\section{DISCUSSION}

The secretion of ghrelin increases with fasting and decreases with fullness. It is known that ghrelin has regulatory affects on body weight (14). The blood ghrelin levels were found lower in obese people when compared with non obese individuals and it is also reported that weight loss increases blood ghrelin levels. Ghrelin regulates body weight via insulin (4). Insulin has regulatory action on ghrelin levels. Increase in insulin levels suppresses ghrelin (15). It is shown that serum ghrelin levels decreases when insulin resistance increases in Type 2 diabetes patients and the patients with insulin resistance and vice versa (16).

Recently, in a study that evaluating the relationship between urticaria and MetS, serum glucose, trygliceride levels and the rates of central obesity were found higher significantly in recalcitrant chronic urticaria patients than the controls. The prevalance of MetS was also significantly higher in the urticaria group. In the same study, it is also declared that the serum levels of tumour necrosis factor- $\alpha$, complements, eosinophilic cationic protein were higher in the patients with MetS (8). Another study reported that hypertension, which is a component of MetS, prolongs the duration of the disease in urticaria patients (17).

Atopic dermatitis is accepted as an organ spesific manifestation of atopic complex which consists of allergic skin changes, allergic rhinoconjunctivitis and asthma. Peripheral eosinophilia and high serum IgE levels may be associated with atopic dermatitis. Immune dysregulation in Th2 pathway and skin barrier dysfunction are considered in the pathogenesis of atopic dermatitis (2). There are studies reporting that atopic dermatitis may be a risk factor for MetS. Silverberg et al reported that obesity in adults induced relapses in atopic dermatitis 
(9). It was demonstrated that obesity lasting more than two and a half year in early childhood was a risk factor for atopic dermatitis (18). There was a relation between obesity and asthma because pro-inflammatory mediators secreted from adipose tissue had some affect on mast cells. In addition, a positive correlation was demostrated between the serum levels of total cholesterol, LDL cholesterol and atopy in school-age children (2). Ma et al (19) detected that insulin resistance did not induce asthma attacks in atopic or non-atopic asthma patients and they reported that atopy and asthma had no relation with obesity and insulin resistance.

There is no study evaluating the serum ghrelin levels in chronic urticaria and atopic dermatitis patients in the literature. However, there are some studies reporting the relation between atopy, asthma, obesity and ghrelin. Cobanoglu et al (20) declared that there was no difference between the serum ghrelin levels of the children with asthma and the children without asthma. They also reported that there is no correlation between BMI and ghrelin. Okamatsu et al (21) reported that there was negative correlation between serum $\operatorname{IgE}$ and ghrelin levels in overweight children and there was no correlation between BMI and ghrelin.

Metabolic system and immune system are closely related to each other. Interactions between these systems increase especially in stress and diseases to keep the balance of the organism (22). Ghrelin is a potent anti-inflammatory hormone. It supresses the production of pro-inflammatory cytokines secreted from activated T-lymphocytes, monocytes, endothelial cells (23). In addition, ghrelin has been found to inhibit the proliferation of anti-CD3 activated T-lymphocytes. Th1 cytokines (IL-1 and IFN- $\gamma$ ) and Th2 cytokines (such as IL-4 and IL-10) which induce IgE synthesis in rodent' spleen were inhibited by ghrelin (24).

Elevated serum ghrelin levels in atopic dermatitis may occur in order to suppress Th2 cell predominance which is considered to be an important patogenetic factor of the disease. It is reported that ghrelin induced the release of histamine from rat peritoneal mast cells (25). Increased ghrelin release may induce the secretion of histamin in chronic urticaria. 
In conclusion, we have found significantly higher serum ghrelin levels in chronic urticaria and atopic dermatitis patients than the controls. We did not find any correlation between ghrelin levels and MetS, BMI and insulin resistance. Therefore, we thought that new studies are needed to disclose if ghrelin plays a role in urticaria pathogenesis.

\section{ACKNOWLEDGEMENT}

Financial Support and Conflict of Interest: None 


\section{REFERENCES}

1. Darlenski R, Kazandjieva J, Zuberbier T, Tsankov N. Chronic urticaria as a systemic disease. Clin Dermatol 2014; 32: 420-3.

2. Darlenski R, Kazandjieva J, Hristakieva E, Fluhr JW. Atopic dermatitis as a systemic disease. Clin Dermatol 2014; 32: 409-13.

3. Kojima M, Kangawa K. Ghrelin: structure and function. Physiol Rev 2005; 85: $495-522$.

4. Aydın S. Discovery of ghrelin hormone. research and clinical applications. Turk J Biochem 2007; 32: 76-89.

5. Lely van der AJ, Tschop M, Heiman ML, Ghigo E. Biological, physiological, pathophysiological, and pharmacological aspects of ghrelin. Endocr Rev 2004; 25: $426-57$.

6. McLaughlin T, Abbasi F, Lamendola C, Frayo RS, Cummings DE. Plasma ghrelin concentrations are decreased in insulin-resistant obese adults relative to equally obese insulin-sensitive controls. J Clin Endocrinol Metab 2004; 89: 1630-5.

7. Cong WN, Golden E, Pantaleo N, White CM, Maudsley S, Martin B. Ghrelin receptor signaling: a promising therapeutic target for metabolic syndrome and cognitive dysfunction. CNS Neurol Disord Drug Targets 2010; 9: 557-63.

8. Ye YM, Jin HJ, Hwang EK, Nam YH, Kim JH, Shin YS et al. Co-existence of Chronic Urticaria and Metabolic Syndrome: Clinical Implications. Acta Derm Venereol 2013; 93: 156-60.

9. Silverberg JI, Silverberg NB, Lee-Wong M. Association between atopic dermatitis and obesity in adulthood. Br J Dermatol 2012; 166: 498-504. 
10. Hanifin J, Rajka G. Diagnostic features of atopic dermatitis. Acta Derm Venereol 1980; 92: 44-7.

11. Physical status: the use and interpretation of anthropometry: report of a WHO expert committee. WHO Tech Rep Ser 1995; 854: 1-452.

12. Alberti KG, Zimmet P, Shaw J. IDF Epidemiology Task Force Consensus Group. The metabolic syndrome a new worldwide definition. Lancet 2005; 366: 1059-62.

13. Matthews DR, Hosker JP, Rudenski AS, Naylor BA, Treacher DF, Turner RC. Homeostasis model assessment: insulin resistance and beta-cell function from fasting plasma glucose and insulin concentrations in man. Diabetologia 1985; 28: 412-9.

14. Chan JL, Bullen J, Lee JH, Yiannakouris N, Mantzoros CS. Ghrelin levels are not regulated by recombinant leptin administration and/or three days of fasting in healthy subjects. J Clin Endocrinol Metab 2004; 89: 335-43.

15. Anderwald-Stadler M, Krebs M, Promintzer M, Mandl M, Bischof MG, Nowotny P et al. Plasma obestatin is lower at fasting and not suppressed by insulin in insulinresistant humans. Am J Physiol Endocrinol Metab 2007; 293: 1393-8.

16. Poykko SM, Kellokoski E, Horkko S, Kauma H, Kesaniemi YA, Ukkola O. Low plasma ghrelin is associated with insulin resistance, hypertension, and the prevalence of type 2 diabetes. Diabetes 2003; 52: 2546-53.

17. Nebiolo F, Bergia R, Bommarito L, Bugiani M, Heffler E, Carosso A et al. Effect of arterial hypertension on chronic urticaria duration. Ann Allergy Asthma Immunol 2009; 103: 407-10.

18. Silverberg JI, Kleiman E, Lev-Tov H, Silverberg NB, Durkin HG, Joks R et al. Association between obesity and atopic dermatitis in childhood: a case-control study. J Allergy Clin Immunol 2011; 127: 1180-6. 
19. Ma J, Xiao L, Knowles SB. Obesity, insulin resistance and the prevalence of atopy and asthma in US adults. Allergy 2010; 65: 1455-63.

20. Cobanoglu N, Galip N, Dalkan C, Bahceciler NN. Leptin, ghrelin and calprotectin: inflammatory markers in childhood asthma? Multidiscip Respir Med 2013; 8: 62.

21. Okamatsu Y, Matsuda K, Hiramoto I, Tani H, Kimura K, Yada Y et al. Ghrelin and leptin modulate immunity and liver function in overweight children. Pediatr Int 2009; 51: 9-13.

22. Dixit VD, Dennis D. Taub Ghrelin and immunity: A young player in an old field. Exp Gerontol 2005; 40: 900-10.

23. Li WG, Gavrila D, Liu X, Wang L, Gunnlaugsson S, Stoll LL et al. Ghrelin inhibits proinflammatory responses and nuclear factor-B activation in human endothelial cells. Circulation 2004; 109: 2221-6.

24. Xia Q, Pang W, Pan H, Zheng Y, Kang JS, Zhu SG. Effects of ghrelin on the proliferation and secretion of splenic T lymphocytes in mice. Regul Pept 2004; 122: $173-8$.

25. Hirayama T, Kawabe T, Matsushima M, Nishimura Y, Kobe Y, Ota Y et al. Ghrelin and obestatin promote the allergic action in rat peritoneal mast cells as basic secretagogues. Peptides 2010; 31: 2109-13. 